\title{
Cultural Features Reflected in Polish and Vietnamese Proverbs
}

\author{
Thi Thu Thuy Nguyen \\ Ph.D., Ho Chi Minh City University of Culture (Ho Chi Minh City, Vietnam) \\ E-mail: 2002trunghanguyen@gmail.com \\ https://orcid.org/0000-0003-4649-6892
}

Nguyen, Thi Thu Thuy (2020) Cultural Features Reflected in Polish and Vietnamese Proverbs. Future Human Image, Volume 13, 2020: 76-87. https://doi.org/10.29202/fhi/13/8

Proverbs as a section of language are a folklore genre that contains much knowledge, wisdom, philosophy, behavior of nations. Research on proverbs themselves is always an interesting job attracting many scholars. More particularly, research on proverbs as tools by language-culture relationship perspective to deeply understand cultures is a much harder task. Using an interdisciplinary approach and typological method in Comparative cultural studies based on the data of more than 151 proverbs processed, the findings of this article will introduce some cultural features of Polish and Vietnamese people as well as East and West. It is just a channel to prove that research on proverbs can help research on culture to affirm the differences and similarities in thought and behavior. Accordingly, this will help the communication and cultural interchange, cooperation, and education better and more effectively.

Keywords: proverbs, sayings, Polish culture, Vietnamese culture, comparative cultural studies

Received: March 10, 2020; accepted: March 29, 2020

\section{Introduction}

Proverbs are a section of language as well as a section of culture. The relationship between language and culture has been an interesting research topic of scholars, including the relationship between proverbs and culture. It is so simple and certainly that human culture in general and a national culture, in particular, has been recorded and preserved in language and by language. An element of language always contains both aspects: the linguistic features and the cultural features. Therefore, proverbs truly are such a phenomenon. In proverbs, we can find linguistic ingredients, and these are everyday communicative words of humankind; we can find lots of moral lessons, thoughts, worldview, ideology of an ethnic group or a nation. Proverbs, in fact, are a channel to understand culture and disclose some cultural features of a nation.

Nowadays, the interchange and cooperation of many countries on various scales and fields require understanding in using foreign languages in communication. The needs to study foreign languages and understand culture become more and more urgent. Vietnam and Poland have

(C) Nguyen, Thi Thu Thuy, 2020 
had long, beautiful cooperation and durable friendship. We are so researching the language and culture of the two countries always necessary and meaningful. By writing this article, we would like to contribute our little help to make these processes more effective and better through the findings of differences and similarities in the cultural features of both nations refracted in their proverbs.

\section{Literature review}

\section{Proverb concept}

Proverbs are short, memorable expressions or sayings in every language. They belong to folklore of a nation, commonly appear in everyday communication. In Vietnamese proverbs mean "Tục ngữ," or "Przysłowie" in Polish, they have a variety of concepts and definitions. For example, in Collins Dictionary, a proverb is "a short, memorable, and often highly condensed saying embodying, esp with bold imagery, some commonplace fact or experience" (Collins Dictionary, 2020). In Cambridge advanced learner's dictionary (Cambridge dictionary, 2013), a proverb is just as simply "a short sentence, etc., usually known by many people, stating something commonly experienced or giving advice." Some scholars do not clarify a proverb with its equivalence like a saying, or "Speakword." Idioms Polsko-Angielskie (Polish — English idioms) confirmed that the borderline between proverbs and sayings is a difficult one to establish (Wolfram-Romanowska et al., 1999: 16). So, in terms of their usage, proverbs often function as sayings.

In our article, to have a wider way to approach our topic, we accept and use a concept considering a proverb is a short expression of popular wisdom in a language. In our data collection, we enter the sayings, expressions, or "speak words" as equivalent sentences in the comparison process.

Proverbs are complete sayings, summarizing the people's experience about nature and productive labor, about people and society. They are intellectual, so often likened to "folk wisdom." Especially, that intelligence is very deep but also very diverse and expressed in short, concise words, easy to remember, rich in images and rhythms.

Proverbs are formed from real life, in production and struggle of the people, directly composed by unknown people using linguistic ingredients from things and images, trees, tools, animals, etc ... associated with daily life, from literary works or from foreign borrowing.

By observing things, specific phenomena, people are directly aware of phenomena and things through their external manifestations, then they discovered behind direct perception is the nature if abstracted of those particular phenomena. "We can see the vast majority of the figurative/symbolic meanings of proverb formed according to the dialectical rule of perception "From vivid visualization $\rightarrow$ Abstract thinking $\rightarrow$ Reality" (Pham, 2008: 64). When discussing the meaning of proverbs, most researchers agree that they have two kinds of meaning: literal and figurative or symbolic meaning. The former is direct meaning originating from the linguistic ingredients. The latter is formed from the use of specific images to reflect the generalization, the rules using measures like comparison, personalization, and metaphor. Tran Manh Thuong (Tran, 1996) affirmed that proverbs often use images, events, phenomena, concrete realities in social life, and nature to generalize into ideas abstract...Therefore, each proverb always implies two meanings: literal and figurative meaning. The individual particulars will form the literal meaning while the abstract, common one forms the figurative meaning. Besides, according to Pham Thanh Hang (Pham, 2008: 59), in reality, "there are proverbs that merely have literal meaning (explicit meaning), but the number of these sentences is not much, mainly 
summarize agricultural production experiences. In usage of proverbs, the meaning of each proverb not only depends on the understanding of the original composers, but also depends very much on the conception and usage of the users later".

\section{Data and research methodology}

In this article, we have applied some of the approaches and methods as the followings:

1. Data collection and procession methods are employed to collect proverbs and/or sayings, and then they are entered in Excel, explained or translated to find linguistic ingredients and meanings. This manipulation will help us to open the cultural features of the two languages. The data for Polish proverbs is basically based on three sources or providers:

a) Polish proverbs on (Polish proverbs, 2020) contrasted to proverbs in the book Idiomy Polsko-Angielskie (Polish — English idioms) (Wolfram-Romanowska et al., 1999).

b) Polish proverbs collected by Mikołaj Gliński in his articles "The Eternal Wisdom of Polish Proverbs" and "Odd Phrases Poles Love to Use" (Gliński, 2017; Gliński, 2018).

c) From the personal collection of Prof. Dr. Tran Vinh Hung (Institute of Low Temperatures and Structure Research Polish Academy of Sciences, Poland)

Certainly, while processing the data, we have done the translation twice. At first, we use the word - for - word translation to find typically linguistic materials in Polish. Secondly, we translate to find the meanings of those proverbs. In other words, we interpret the literal and figurative meanings of these proverbs. Then we contrast and compare these proverbs, classify them into categories. From the categories, we discover and analyze our findings based on our processed data. We can see the results in the next part of the article.

2. The interdisciplinary approach applied quite effectively in this article as a "so-called" "umbrella" approach to analyze and interpret the relationship between language and culture. Because people only have the theories or perspectives to study the relationship between language and culture that proverbs are just a small linguistic section. Studying language to understand culture since language is a system of symbols - an intricate, typical, and thorough system, as well as the soul of a nation. This relationship was argued by Claire Kramsch (Kramsch, 1998: 3) in the book Language and culture as this: language expresses cultural reality, language embodies cultural reality, and language symbolizes cultural reality. Edward Sapir - an American anthropologist-linguist mentioned language, race and culture in the book Language - an introduction to the study of speech (Sapir, 1921) also proved that "language does not exist apart from culture, that is, from the socially inherited assemblage of practices and beliefs that determines the texture of our lives." Therefore, by researching proverbs a section of language, definitely, we can ascertain cultural characteristics in using materials to make meanings for proverbs and the thought and worldview that people imply in their proverbs.

3. Comparative cultural studies have been used parallel to the interdisciplinary approach. Comparing two or more things/objects to discover the differences or similarities has the main scientific manipulation for a long time. Though comparison between languages and cultures has been applied for approximately several decades, marked by the names of Steven Tötösy de Zepetnek with the publication "From Comparative Literature Today Toward Comparative Cultural Studies" in which he pointed out ten principles of comparison (Tötösy de Zepetnek, 
1999). Tötösy de Zepetnek confirmed that "comparative cultural studies are a field of study in the humanities and social sciences where tenets of the discipline of comparative literature are merged with the field of cultural studies; the objects of study are all sorts of culture and culture products" and "comparative cultural studies are no master theory, but one framework among several others; they have to be tested and applied, and to be used as a tool in order to understand and to produce new knowledge" (Tötösy de Zepetnek, 2003:1). In practice and from an academic viewpoint, the method in comparative cultural studies favors the systemic and empirical approach with the basic purposes are determining the universality of human culture and proving the particularity of national culture. Tötösy de Zepetnek once emphasized comparative cultural studies is an inter-and multi-disciplinary approach borrowing from a number of areas in the humanities and social sciences, including (radical) constructivism, systems theories, the empirical, cultural anthropology, ethnology, reception theory, the sociology of knowledge, cognitive science, etc." (Tötösy de Zepetnek, 2003: 3).

Comparative cultural studies has been proved usefulness in modern Age when people need to know deeper in linguistic and cultural fields to serve the interchange, cooperation better. Its purposes, originally, are to bring new and objective insights into the similarities and differences of cultures as well as provide us with more in-depth knowledge and a profound understanding of cultures in order to live better, more harmoniously without a sense of higher appreciation or contempt for any cultures. Thus, any culture, any element of a culture, can be the object of comparative cultural studies. Indeed, it is right for proverbs. In this article, from the framework of comparative cultural studies (Tötösy de Zepetnek, 2003), we applied the typological method to research Polish and Vietnamese proverbs. Our interesting findings will help the mutual understanding of Eastern and Western cultures generally speaking, and Polish and Vietnamese cultures particularly speaking, hence foster the communication and cultural interchange better and more effectively.

\section{Characteristic meanings in Polish and Vietnamese proverbs}

Based on 151 proverbs collected, interpreted, compared, and classified except for some sayings which do not have equivalent expressions in Vietnamese or they cannot make a group or classification, the process results are shown on the below table.

Table 1: Kinds of meaning of Vietnamese and Polish proverbs

\begin{tabular}{|l|l|c|c|c|c|}
\hline \multirow{2}{*}{ Kinds of meaning } & \multicolumn{2}{c|}{ Vietnamese proverbs } & \multicolumn{2}{c|}{ Polish proverbs } \\
\cline { 2 - 6 } & Quantity & Percentage & Quantity & Percentage \\
\hline \multicolumn{2}{|c|}{ 1.Literal meaning } & 22 & $14,57 \%$ & 9 & $5,96 \%$ \\
\hline \multirow{2}{*}{$\begin{array}{l}\text { 2.1.Accumulative } \\
\text { Figurative } \\
\text { meaning }\end{array}$} & $\begin{array}{l}\text { relationship } \\
\text { 2.2.Cause - result } \\
\text { relationship }\end{array}$ & 15 & $9,93 \%$ & 11 & $7,28 \%$ \\
\cline { 2 - 6 } & $\begin{array}{l}\text { 2.3.Comparative } \\
\text { relationship }\end{array}$ & $\mathbf{4 8}$ & $\mathbf{3 1 , 7 9 \%}$ & $\mathbf{4 0}$ & $\mathbf{2 6 , 4 9 \%}$ \\
\cline { 2 - 6 } & $\begin{array}{l}\text { 2.4.Oppositional } \\
\text { relationship }\end{array}$ & 24 & $15,89 \%$ & 25 & $16,56 \%$ \\
\cline { 2 - 6 } & 2.5.Metaphor & 16 & $10,60 \%$ & $\mathbf{3 9}$ & $\mathbf{2 5 , 8 3 \%}$ \\
\hline
\end{tabular}




\begin{tabular}{|c|c|c|c|c|}
\hline Exception & 10 & $6,62 \%$ & 10 & $6,62 \%$ \\
\hline Total & $\mathbf{1 5 1}$ & $\mathbf{1 0 0} \%$ & $\mathbf{1 5 1}$ & $\mathbf{1 0 0} \%$ \\
\hline
\end{tabular}

\section{The similarities}

From the above classification table, we can see that Vietnamese proverbs and Polish proverbs have many similarities, even Vietnamese and Polish belong to two different linguistic types. They have the universality in the classification of meaning categories of proverbs: literal meaning and figurative meaning. Continuously, categorizing figurative meaning of proverbs based on the processed data, five measures to form the symbolic meaning of proverbs have been disclosed. Amongst them, forming meaning using a comparative relationship is the most common with the highest percentage, both in Vietnamese (32\%) as well as Polish (26\%). The next measures are oppositional relationship (approximately 16\%) and cause - result relationship (about 11\%). Metaphor method is quite common in Polish with a percentage of $26 \%$ but not as so popular in Vietnamese with a percentage of less than $10 \%$. What is more, while classifying the data, we also discover many proverbs in both languages can be simultaneously arranged into two different categories. Thus, the result of the classification is quite relative, a bit subjective, not totally absolute.

The literal meaning of Vietnamese and Polish proverbs both have a similar form in creating meaning from direct senses of the linguistic ingredients without any interpretation or deduction. For example, mentioning a person who has a soft and gentle voice like honey but their behavior is so rude and unacceptable to other people, the Polish people use "Anielskie usta a szatanskie serce." while Vietnamese people will say "Khẩu phật tâm xă" or "Miệng Nam Mô, bụng một bồ dao găm." Or "Bóg pomaga temu, który sam rozwiqzuje własne problemy" with equivalences in Vietnamese proverbs like "Hãy tụ cứu minh truớc khi trời cứu" or "Tụ luc cánh sinh" with the same meanings "Try your best, the rest God will do" or "God helps those who help themselves." The two nations advise people to live independently and be selfresponsible, not depending on the help of others.

The data shows the comparative relationship is the most popular meaning-forming type in the category of figurative meaning. It is also shown that 40 Polish proverbs translated into Vietnamese, there are 24 proverbs with similar comparative relationship like the original ones, the percentage here $60 \%$. Moreover, the similarity is found in the proverbs about love. Polish and Vietnamese cultures compare love with other elements like: money, beauty, passion, sorrow, dream, award, pink, death, mistake, animal...We all see that humans always need love, mention, praise, adore, despair about love. This is the category in life for which humans waste lots of paper and ink. These examples are just some to prove that.

Polish and Vietnamese proverbs compare love with horse: love is like a wild (uncontrolled or untamed) horse.

"Miłość - uparta jak koń narowisty, a kapryśna jak dziecko."

"Tình yêu nhu con ngựa bất kham."

Love is like a child of the dream, but parents of the hopelessness.

"Miłość jest dzieckiem marzeń, a rodzicem rozczarowań."

"Yêu là mơ mộng."

Love is like a biggest award of love, or the Creator saved for humans.

"Miłość jest największa nagroda za miłość."

"Tình yêu là phần thương lớn mà tạo hóa dành cho con người." 
Metaphor is one of the most common meaning-forming types in proverbs. Because, most of the proverbs have two kinds of meaning, and the figurative meaning is more important since it contains thoughts, lessons, morality, worldview to which humans want to "confide." Metaphor is our data shows a higher percentage in Polish than in Vietnamese. This is because the difference may relate to the distinctive type of language of Vietnamese and Polish (Vietnamese belongs to Isolating type while Polish is Inflecting/metamorphic type), or our data is still limited, the difference here has not been proved authenticity. In Polish culture, in order to say "Too many cooks spoil the broth," they use "Gdzie kucharek sześć, tam nie ma co jeśc."; in Vietnamese culture, they have the saying "Lắm thầy, rầy ma." (literal meaning like many shamans will trouble the ghosts). But they all have general meaning if there are too many people doing one task together, the result will be spoiled. Another example with the meaning of flexible behavior, the Poles use "Kiedy wejdziesz między wrony musisz krakać tak jak one." (meaning Once among the crows, caw as they do) or "Kruk krukowi oka nie wykole." (meaning When in Rome, do as the Romans do), then Vietnamese will say "Nhạp gia tùy tuc" with the same meaning.

Other meaning-forming types in Polish and Vietnamese proverbs using accumulative relationship, cause - result relationship, and oppositional relationship are often common in both languages with similar numbers and percentages shown on the table. Here, we can say that they are not only universal in meaning-forming measures but also thoughts and worldview.

In accumulative relationship, these proverbs use words belonging to one category or structures in which the second part of the saying modifies or adds meaning for the first. Examples: the word "ognia" in proverb 1, the words "chleb" and "bułki" in proverb 2.

(1) Nie potrzeba ognia do ognia przydawać.

(2) Kto ma chleb, szuka bułki

In Vietnamese proverb, they also use "dầu" (fuel) and "lửa" (fire) of one category in proverb 1: "Đìng đổ thêm dầu vào lìa" (Do not add fuel to the fire.)

In proverb 2, Vietnamese people use the relationship type: the second part of the saying modifies or adds meaning for the first "được voi" (getting an elephant), "đòi tiên" (asking for a fairy) to imply the human greed.

In the case of cause - result relationship, Polish and Vietnamese proverbs usually have two parts in which the second part of the saying is the result of the first. This is so recognizable in each proverb. Example "Jaka praca, taka płaca" in Polish means "làm sao huoơng vâyy" (you are paid well, if you work well.) "Bez pracy nie ma kołaczy." means "không gieo thi đù̀ng gặt." like "no pain, no gain."

The oppositional relationship is found in proverbs that have two parts in which they have opposite meanings or structures. Sometimes proverbs with one structure, but they have the same characteristic. For examples: good $<>$ bad; gain $<>$ lose; life $<>$ death; infamy $<>$ honor; happiness $<>$ unluck; forward $<>$ backward; on the car $<>$ under the car; coming $<>$ going... are of so popular. Some proverbs in this groups are:

(1) "Raz na wozie, raz pod wozem." in Polish

"Phúc bất trùng lai, họa vô đơn chí." in Vietnamese

Both mean "Misery loves company. Misfortunes come in pairs."

(2) "Łatwo przyszło, łatwo poszło." in Polish

"Dễ đến, dễ đi" in Vietnamese

Both mean "Easy come, easy go." 


\section{The differences}

Proverbs as a folklore genre contain a fragment of the language picture of the world of a nation, the reality of a nation through their distinctive linguistic ingredients. Claire Kramsch confirmed that (Kramsch, 1998: 85):

"Human beings do not live in the objective world alone, nor alone in the world of social activity as ordinarily understood, but are very much at the mercy of the particular language which has become the medium of expression for their society... The fact of the matter is that the "real world" is to a large extent unconsciously built up on the language habits of the group. No two languages are ever sufficiently similar to be considered representing the same social reality."

Therefore, proverbs not only contain human universalities in values, thoughts, wisdom, worldview but also express the differences of each nation, each culture. It is said the proverbs bear the national characteristics, cultural identity. This is clarified in linguistic materials associated with the social reality of a nation to create proverbs shown on the table below:

Table 2: Linguistic ingredients of Vietnamese and Polish proverbs

\begin{tabular}{|l|c|c|c|c|}
\hline \multirow{2}{*}{ Language ingredients } & \multicolumn{2}{c|}{ Vietnamese proverbs } & \multicolumn{2}{c|}{ Polish proverbs } \\
\cline { 2 - 5 } & Quantity & Percentage & Quantity & Percentage \\
\hline Animal & 9 & $5,96 \%$ & 16 & $10,60 \%$ \\
\hline Parts of body & $\mathbf{1 8}$ & $\mathbf{1 1 , 9 2 \%}$ & 11 & $7,28 \%$ \\
\hline Food \& drink & 11 & $7,28 \%$ & $\mathbf{2 8}$ & $\mathbf{1 8 , 5 4 \%}$ \\
\hline Number & 3 & $1,99 \%$ & 6 & $3,97 \%$ \\
\hline Nature \& Supernature & 13 & $8,61 \%$ & 8 & $5,30 \%$ \\
\hline Specific things/tools & $\mathbf{2 6}$ & $\mathbf{1 7 , 2 2 \%}$ & 16 & $10,60 \%$ \\
\hline Others & $\mathbf{6 9}$ & $\mathbf{4 5 , 7 0 \%}$ & $\mathbf{6 6}$ & $\mathbf{4 3 , 7 1 \%}$ \\
\hline Total & $\mathbf{1 5 1}$ & $\mathbf{1 0 0 \%}$ & $\mathbf{1 5 1}$ & $\mathbf{1 0 0 \%}$ \\
\hline
\end{tabular}

Table 2 shows us considerable differences in Polish and Vietnamese proverbs. Vietnamese proverbs tend to use specific things/tools (17\%) and parts of the body $(12 \%)$ to create meanings, while Polish proverbs orientate towards using food and drink (19\%). "Others" is a group of abstract ideas or things that cannot be divided into categories. There is a tight relationship between social or cultural reality with linguistic materials or simply "language expresses cultural reality," as Claire Kramsch above confirmed (Kramsch, 1998: 3). This has made the diversity and richness for proverbs as well as contributed to the distinction of proverbs and each culture.

Poland is located in Central Europe, has temperate weather. In tradition, it was an agricultural country which orientated towards cultivating cabbage, potatoes, canola, apples and feeding pigs, cows. Popular kinds of food have been made from those produced materials like bread, cabbage, milk, sausages. Coincidently, food and drink are two common linguistic ingredients to form meanings for Polish proverbs with the highest percentage (except for "others" group). 
Examples of proverbs using "bread" as a material to produce meanings:

"Chleb $i$ woda - nie ma głoda." (meaning Bread and water - no hunger.)

Chleb praca nabyty, bywa smaczny $i$ syty. (meaning Bread acquired by work can be tasty and full.)

Każdy cudzy chleb ma rogi. (meaning Everyone else's bread has horns.)

Głodnemu ciagle chleb na myśli. (meaning The hungry still mean bread.)

Nie samym chlebem człowiek żyje. (meaning Man does not live by bread alone.)

Jaki chleb, taka skórka - jaka matka, taka córka. (meaning What bread, such a crust -

Like a mother, such a daughter)

Examples of proverbs using "drinks" like milk, beer as a material to produce meanings.

Nie czas płakać nad rozlanym mlekiem. (meaning Don’t cry over spilt milk/ Let bygones be bygones.)

Nawarzyles sobie piwa to je sam wypij. (meaning If you brew your own beer, drink it yourself.)

Pij, bracie, pij, na starość torba i kij. (meaning Drink is not a good habbit.)

While Vietnamese proverbs on this table point out a few saying containing materials which belong to food and drink. There are some common words meaning food in Vietnamese meals like rice (cơm), noodle (phở), crab (cua), shrimp (tép), lobster (tôm), soup (canh)... For instance

Chán corm thèm phở. (meaning when you are bored with rice, you can enjoy noodles. the more you get, the more you want)

Con sâu làm rầu nồi canh. (meaning A worm can spoil a pot of soup./ One scabby sheep is enough to spoil the whole flock)

Thả con tép bắt con tôm. (meaning using a shrimp as a bait to catch a lobster./ Set a herring to catch a whale.)

Vietnamese people tend to use specific tools or things in life and parts of the body to create meanings for proverbs. These features are not so common in Polish proverbs.

We can find many specific tools or things in life in Polish proverbs like axe (siekiera), razors (brzytwy), bed (pościelesz), bowl (miska), pot (garnka)... For example: "Wrzucac wszystko do jedngo garnka." (meaning Throw everything to one pot.)

In Vietnamese proverbs, these are such words like skin of fruits (water melon skin; coconut skin), pole, needle, bag, sieve, clothes, wood, paint, box, basket, handle... For example, "Gio nha ai quai nhà nấy" (mean the handle always belongs to its basket./ What bread, such a crust — like a mother, such a daughter.)

Parts of body like mouth, heart; head, tail; eyes and ears in love; face; legs and arms; bone, nose... and abstract or general elements of human beings like mind, soul, appearance, memory... seem so popular in both types of proverbs.

Examples:

Mouth and heart, or head and tail in these proverbs:

Khẩu phật tâm xà. (meaning mouth/speaking like a Buddhist but heart like a snake./ A honey tongue and a heart of gall.)

Đầu xuôi đuôi lọt. (meaning the head passes will facilitate the tail to pass./ A bad beginning makes a bad ending.)

Kto nie ma pamięci, nogami musi nadrabiać. (meaning Whoever has no memory has to make up his legs.) 
What is more, the animals in Polish proverbs are those Polish symbol culture like bear, crow, awl, wolf, horse, cat, hare... while in Vietnamese proverbs, there are buffalo, sparrow, flamingo, elephant, snake...

Animals always played an important role among people. Ivan R., in the article Animal Symbolism in Slavic cultures: Wolf, Bear, Fox and Hare agreed that "animals such as wolves, bears, hares or foxes thanks to the wide area of distribution firmly entrenched themselves in various legends, stories, mythology and art of Slavic people... and these animals left a strong mark on our cultures" (Ivan, 2020).

According to Ivan R., bears have also left such a strong symbolic impact that is representing the whole area (Ivan, 2020). Thanks to the many human-like bear habits, and the ability to stand on its hind legs, the old Slavs believed that the origin of man and bear are closely related. Traditionally, it was a taboo to eat bears meat. The bear was naturally considered as a very clever animal, and people think that his hair, even other "parts," brought not only success, but also the added wisdom to the wearer. Mikołaj Gliński also confirmed that "the bear (Polish: niedźwiedź) is featured prominently in many Polish proverbs and sayings - a likely trace of a one-time ubiquitous presence of these wild animals in Polish forests" (Gliński, 2017). For example, when Poles say "Wyświadczyt mi niedźwiedzia przystugę" (meaning $\mathrm{He}$ did me a bear's service.) but in fact the figurative meaning is that "It is better to do nothing" or the proverbs "Nie dziel skóry na niedźwiedziu" (meaning Don't count your chickens before they're hatched.) often used in Polish as a call 'not to divide the skin while it's still on the bear!' simply means we are not certain of our future.

Mikołaj Gliński also discovered that "another wild animal featured prominently in Polish proverbs is the wolf" (Gliński, 2017). "Wolves had an enormous effect on Slavic populations, hence all the legends about werewolves. During early Christianity spread upon these lands, it was banned to eat wolf flesh because it was believed you would become a werewolf afterward. Wolf was always associated with a character of a "stranger," and he was never able to live with people" (Ivan, 2020). Wolf was a symbol of wild, untamed nature, but still, it was an animal that villagers respected mostly out of fear. For example, the proverb "Nosit wilkrazykilka ponieśli iwilka" in Polish is used to express the idea that there's an end to all ruthless actions and this end comes inevitably, no matter how powerful a person seems at the time. This saying, "Nie wywotuj wilka z lasu" means forbidding calling the wolf out of the woods.

Vietnam is an agricultural country with wet-rice culture attached to the agricultural production life of farmers. We can clearly recognize this feature through many proverbs reflecting the peasant life with abundant and rich farming experiences. Buffalo is the first animal image symbolize the farming when people say, "The buffalo is the start of the career" or "The buffalo goes first, then the plow follows." In Vietnamese culture, the buffalo symbol industriousness, gentleness, strength, and agricultural production. In the data table, we can find such proverbs like "Khỏe như trâu" (meaning as strong as a buffalo) or "Trâu chậm uống nước đuc" (meaning if the buffalo comes late, he can only drink muddy water./ Only bones remain for late guests.)

Besides, Vietnamese people consider elephants as close friends, symbols of affluent wealth and richness, strength, and a cultural symbol of the ethnic minorities on the Central Highlands. Elephants are not only useful for people in life since they have been a means of transportation in production and old army activities but also an artistic image in sculpture, molding statues, jewelry, and decorations (visual arts). For examples a Vietnamese proverb says "Tránh voi chăng xấu mặt nào" (meaning Avoiding elephants is not embarrassing.) to teach people how 
to respond, how to treat people; or another one "Đuợc voi, đòi tiên" (mean when someone gets an elephant, he will ask for a fairy.) to criticize the excessive demand or greed of humans.

Nature \& Supernature is a group that clearly shows the distinction of the worldview of the two nations, even the number of proverbs and percentage are not high. In this group, Vietnamese people orientate to choose elements like woods, forest, land, water source, river, sea to be the symbolic elements in proverbs with comparative relationship and cause-result relationship so that they can express the immensity, mystery, endlessness of the nature, people are so tiny creature in front of the Nature Mother. Mentioning Supernatural elements, Vietnamese use the Supernature with the meanings like God, heaven in general, or they use the Buddhist in both cases: the savior and the punishment.

For example, talking about the power of mutual solidarity and love of husband and wife that can make the sea empty, Vietnamese use "Thuận vợ thuận chồng tát biển Đông cũng cạn." Or to express the idea that it is not easy to compare or measure the endlessness of the depth of the human heart with the depth of the sea and river, Vietnamese say "Dò sông dò biến dề dò. Có ai thấy thuớc mà đo lòng nguời.".

Vietnamese proverb with Supernature (trời) "Chay trời không khỏi nắng" (literal meaning People cannot avoid the sunlight. The figurative meaning is that What is supposed to hang, won't drown./ What will be, will be.)

"Hãy tự cứu minh trước khi trời cứu." in Vietnamese means like do it yourself or Try your best, the rest God will do.

"Đi với Bụt mặc áo cà sa, đi với ma mặc áo giấy." (literal meaning if you go with the Buddhist, wear the robes; if you go with the ghost, wear the paper-made clothes.) The figurative meaning is that When you are in Rome, do as the Roman do.

The group of Nature \& Supernature in Polish proverbs are scattered. We can see two quite common elements: the sun and God. The difference is so interesting. Adoring and divinizing God is the Belief and a voluntary activity practiced by most Poles who adhere to Christianity. What is more special, the worldview of Vietnamese people in the Eastern culture takes a horizontal axis as standard so woods, forest, land, water source, river, sea, and the Buddhist as well all lie on the same plane along the width. While, the worldview of Poles in the Western culture takes a vertical axis as standard so the sun, God has made the direct up the height. Some examples of this group are "Bogu ufaj, a ręki przykładaj." (meaning God helps those who help themselves.) and "Bez mitości jak bez stońca - przeżyć trudno." (meaning Life without love as if life without the sun.)

The final distinction in Polish and Vietnamese proverbs can be shown during processing data: when translating Polish proverbs into Vietnamese proverbs, the type of meaning creation also changes. This is because of the differences in linguistic types, as mentioned above, and the distinction in thought of each nation, each culture. Examples are lots of in the data, like Polish proverb "Apetyt rośnie w miare jedzenia" (meaning Appetite grows while you eat /The more you have, the more you want.) uses the accumulative relationship to form meaning, the equivalence when translated into Vietnamese may be more than one sayings like "Đươc đằng chân, lân đằng đầu" but Vietnamese proverbs utilize accumulative relationship and metaphor at the same time.

"Dla późnych gości pozostaja tylko kości" in Polish (meaning Only bones remain for late guests) has a cause - result relationship in meaning-forming type. In contrast, in Vietnamese, the equivalence has metaphor "Trâu chậm uống nước đục" (meaning the buffalo which comes late can only drink muddy water). 
Vietnamese use the comparative relationship to create the meaning for the proverb "Tốt gỗ hơn tốt nước so"n" (meaning the wood is better than the paint or the inside is much better than the outside) while Poles use the oppositional relationship to express it "Eadna miska jeść nie daje" (meaning the beautiful bowl does not give you the delicious food/ Handsome is as handsome does).

\section{Conclusions}

Proverbs are the treasure of knowledge and experience of human beings. The research on the comparison of proverbs of some cultures in the world has been limited by numbers and achievements. We have applied Comparative cultural studies, and interdisciplinary approach to understand Polish and Vietnamese proverbs so as to disclose cultural features of the two nations. The interesting findings of the similarity of the two cultures refracted in proverbs are the thought, morality, wisdom, worldview as well as the sense-forming measures for proverbs. However, the differences are presented in the three characteristics: linguistic ingredients that originate from distinctive social reality, the perspective orientating towards the width or the height, and the change of the sense-forming measures when translating from this language into other.

Those are just our first tiny results, and definitely, the limitations are unavoidable. Accordingly, some improvements should be made in further researches. We may say the proverbs randomly selected for this study are limited in number, and some may lack typicality or suitable implications due to the authors' inadequate ability. So the extensive studies of the two cultures based on proverbs are required in the next researches.

\section{[ㅁ] References}

Buddhology and life (2013) 275 Vietnamese proverbs (275 câu tục ngữ Việt Nam) in Vietnamese proverbs and folk verses (Vietnamese Dictionary of Lê Văn Đức, and Lê Ngọc Trụ). https://phathocdoisong.com/275-cau-tuc-ngu-viet-nam.html (updated 20th, February, 2020)

Cambridge advance learner's dictionary (4 $4^{\text {th }}$ Edition, CD-ROM) (2013). Cambridge.

Collins Dictionary (2020) https://www.collinsdictionary.com/dictionary/english/proverb (updated 30 January, 2020).

Gliński, Mikołaj (2018) 9 Odd Phrases Poles Love to Use. https://culture.pl/en/article/9-oddphrases-poles-love-to-use (updated 30th January, 2020)

Gliński, Mikołaj (2017) The Eternal Wisdom of Polish Proverbs. https://culture.pl/en/article/ the-eternal-wisdom-of-polish-proverbs (updated $29^{\text {th }}$ January, 2020)

Ivan, R. (2020) Animal Symbolism in Slavic cultures: Wolf, Bear, Fox, and Hare. https://www. slavorum.org/animal-symbolism-in-slavic-cultures-wolf-bear-fox-and-hare/ (updated $17^{\text {th }}$ March, 2020)

Kramsch, Claire (1998) Language and culture. Oxford University Press.

Mieder, Wolfgang, and Anna T Litovkina (2006) Old proverbs never die, they just diversify. The University of Vermont, Burlington, The Pannonian University of Veszprém, Veszprém.

Pham Đuc Duong (2013) From culture to cultural studies (Tù văn hóa đến văn hóa hoc). Hanoi: Culture - Information.

Pham Thanh Hang (2008) Further interpretations of Vietnamese proverbs. Journal of Science Ho Chi Minh City Pedagogical University, Vol. 13, 58-68 (Bàn thêm về nghĩa của tục ngữ Việt. Tạp chí Khoa học Đại học sư phạm thành phố Hồ Chí Minh số 13/2008) 
Polish proverbs (2020) https://en.wikiquote.org/wiki/Polish_proverbs (updated 30th January, 2020)

Sapir, Adward (1921) Language - an introduction to the study of speech (ebook). New York: Harcourt, Brace.

Tötösy de Zepetnek, Steven (1999) From Comparative Literature Today Toward Comparative Cultural Studies. CLCWeb: Comparative Literature and Culture, Vol 1. https://doi. org/10.7771/1481-4374.1041

Tötösy de Zepetnek, Steven (2003) Comparative cultural studies and the study of central European culture. Univ. of Halle-Wittenberg, Germany, Vol. 5. http://www.kakanienrevisited.at/beitr/theorie/Stotosy1.pdf (updated 16 January, 2020)

Tran Manh Thuong (1996) Selective Vietnamese folk poetry (Tục ngũ ca dao Việt nam chọn loc). National culture.

Wolfram-Romanowska, Danuta, Przemyslaw Kaszubski and Martin Parker (1999) Idiomy Polsko-Angielskie (Poplish - English idioms). Wydawnictwo Naukowe PWN. Warszawa. 